\title{
FORETELLING YOUR OWN DEATH
}

\author{
Olesya Viktorovna Savenko
}

Teacher, Termez State University, Uzbekistan

\section{ABSTRACT}

In the article, the author examines the works of poets, reveals their "mythical powers" in predictions about global events and about their own death.

KEYWORDS: - Literature, poetry, amazing predictions, one's own death, teasing otherworldly forces, funeral intonations, the gift of prophecy, motives of hopelessness.

\section{INTRODUCTION}

Poets and prose writers often made amazing predictions - both in poetry and in prose; and about global events - and about his own life. It is impossible to predict one's own death, but many writers succeeded in this in some mystical way.

Joseph Brodsky, seven years before his death, had a presentiment that he would not see the 21st century: "The century will end soon, but I will end earlier" [1]. Indeed, he died in 1996.

Andrei Bely wrote the following lines about himself in his poem "To Friends" (1907):

"He believed in a golden radiance,

And he died from the arrows of the sun.

He measured centuries with his thinking,

But could not live his life - this one..."[2]

Andrei Bely received a sunstroke in Koktebel, which caused a stroke upon arrival in Moscow.

Nikolai Rubtsov wrote in one of his poems:

"I will die in the Epiphany frosts

I will die when the crackling birch

But the spring will be full of horror:

On the churchyard river will flood waves!"[3],

- and indeed, his life was cut short on January 19, 1971, during the celebration of Christians' Epiphany. At the time of his death, the poet was only 35 years old.

As practice shows, it is not very useful for writers to call upon death or hasten its arrival, as well as to tease otherworldly forces. E. A. Yevtushenko in his memoir essay about B. L. Pasternak cites the following words of the poet: "Never predict your tragic death, for the power of the word is such that it will lead you to predicting death by self-hypnosis. Remember at least how careless were Yesenin and Mayakovsky with their 
CURRENT RESEARCH JOURNAL OF PHILOLOGICAL SCIENCES 2(7): 40-42,

May 2021 DOI: https://doi.org/10.37547/philological-crjps-02-07-10

ISSN 2767-3758

(C)2021 Master Journals

Crossref dof 81 Google

Accepted26 th July, 2021 \& Published 31 ${ }^{\text {th }} J u l y, 2021$

predictions."

We were convinced of this in the distant past. Thus, the ancient Roman poet Albiy Tibullus, complaining about the intractability of his obstinate lover, kept repeating his desire to "descend into the realm of Pluto" as soon as possible ("Elegy of Ligdam. Introduction.(III, 3)") [4]. His wish came true: he left the world at only 41 years old.

Boris Pasternak himself violated this ban. In the poem "August", not guessing only the month, he paints his future death in all details:

"I'd had a dream. You walked in slow pace.

You headed to my own funeral.

You walked through woods in groups and single file.

And someone made an observation,

That it was August Sixth Old Style -

Our Lord's Transfiguration.

...And in the middle of the wooded space

Was standing Death. As a surveyor,

She looked intently into my dead face

To plan my grave inside the graveyard."[5]

In the verses of the absurdist poet Alexander Vvedenky, according to the observation of researchers, in the last year of his life, funeral intonations appeared: "The disappeared inspiration now comes for a moment, to death, to death, keep equal..." ("Elegy", 1940) [6]. He, who survived the 30s, was arrested after the outbreak of the war and soon died.

The presentiment of the irreparable in one's own destiny can be expressed in different ways. It is expressed in different ways in the literary interpretation of this or that author, who was suddenly touched by the gift of prophecy. The French poet, Alfred de Musset, wrote in one poem:
"I hear the death knell all the time,

Waiting for eighteen months to die

I struggle with insomnia, drag the torment,

And it blows cold from all sides.

The hotter I argue with my sickness,

All the more acutely I foresee trouble,

My heart is weak, I dare not move,

I am afraid: I will step - and I will leave forever ... "(1857)[7]

Alfred de Musset, whose work was infected with the motives of hopelessness and loneliness, lived for 47 years.

No less strange pictures were once presented by the Cuban writer and poet Jose Martí. In his poem "I dreamed of marble chambers ..." in the middle of a huge pile of knowledge, we meet:

"But the hero I hugged

He threw me to the ground with a blow

Your spear and my throat

Has come..."[8]

В феврале 1895 году на Кубе началась национальная освободительная война, и через 3 месяца, 24 мая, Хосе Хулиан Марти-иПерес погиб в бою ДосРиос.

In February 1895, a national liberation war broke out in Cuba, and 3 months later, on May 24, Jose Julian Martí y Perez was killed in the battle of Dos Rios.

\section{REFERENCES}

1. https://scanpoetry.ru/poetry/12280

2. https://www.culture.ru/poems/8143/dru zyam 
CURRENT RESEARCH JOURNAL OF PHILOLOGICAL SCIENCES 2(7): 40-42,

May 2021 DOI: https://doi.org/10.37547/philological-crjps-02-07-10

ISSN 2767-3758

(C)2021 Master Journals

Crossref dof 81 Google

Accepted26 thJuly, 2021 \& Published 31 th July, 2021

3. https://www.culture.ru/poems/40927/ya

-umru-v-kreshenskie-morozy

4. http://simposium.ru/ru/book/export/ht

$\mathrm{ml} / 10391$

5. https://www.culture.ru/poems/13967/av gust

6. https://slova.org.ru/vvedenskiy/elegiya_o smatrivaya/

7. https://mir-knig.com/stihi/read/29974

8. http://www.vivacuba.narod.ru/josemarti.htm\#14

9. Ryzhov A. Literary prophets. M .: Eksmo, 2007. 